Published in Modern Intellectual History 14 (2017), 689-715. Copyright Cambridge

University Press. PDF of published version: https://doi.org/10.1017/S1479244315000293

\title{
Virtue Language in Nineteenth-Century Orientalism: A Case Study in Historical
}

\section{Epistemology}

Herman Paul

Institute for History, Leiden University

E-mail: h.j.paul@hum.leidenuniv.nl

Historical epistemology is a form of intellectual history focused on "the history of categories that structure our thought, pattern our arguments and proofs, and certify our standards for explanation” (Lorraine Daston). Under this umbrella, historians have been studying the changing meanings of "objectivity," "impartiality," “curiosity," and other virtues believed to be conducive to good scholarship. While endorsing this historicization of virtues and their corresponding vices, the present paper argues that the meaning and relative importance of these virtues and vices can only be determined if their mutual dependencies are taken into account. Drawing on a detailed case study - a controversy that erupted among nineteenthcentury Orientalists over the publication of R. P. A. Dozy's De Israëlieten te Mekka (The Israelites in Mecca, 1864) - the paper shows that nineteenth-century Orientalists were careful to examine (1) the degree in which Dozy practiced the virtues they considered most important, (2) the extent to which these virtues were kept in balance by other ones, (3) the extent to which these virtues were balanced by other scholars' virtues, and (4) the extent to which they were expected to be balanced by future scholars' work. Consequently, this paper argues that historical epistemology might want to abandon its single-virtue focus so as to allow balances, 
hierarchies, and other dependency relations between virtues and vices to move to the center of attention.

\section{Introduction}

In December 1863, Karl Marx paid a visit to his Dutch uncle Lion Philips in Zaltbommel. ${ }^{1}$ One of the striking things he discovered during his stay in this Dutch city was that Biblical criticism made quite a furor in the Netherlands, not only among academic theologians, but also among liberal Protestant pastors who welcomed Biblical criticism as a means for liberating religious practice from what they perceived as the "chains" of dogma and tradition. ${ }^{2}$ "Here in Holland," Marx wrote in January 1864 to Friedrich Engels, "the German criticaltheological tendency is so very much à l'ordre du jour that the parsons acknowledge it openly

\footnotetext{
${ }^{1}$ A draft of this paper was presented at the "Nineteenth and Twentieth-Century Philological Encounters" conference at Leiden University on 5 June 2014. I would like to thank the audience on that occasion for their helpful feedback as well as Henning Trüper, the editors of this journal, and four anonymous reviewers for important queries and suggestions. Unless otherwise noted, all translations are mine. Funding was generously provided by the Netherlands Organization for Scientific Research (NWO).

2 "Liberal theology" is the customary English rendering of what, from the 1850s onwards, was known in the Netherlands as "moderne theologie." See, e.g., [D. Th. Huet], Wenken opzigtelijk moderne theologie (The Hague, 1858) and the debate elicited by this anonymous pamphlet. Although liberal theologians in the 1850s and 1860s fought several battles at once, their uncompromising commitment to Biblical criticism was one of their most important and most contested hallmarks. See Mirjam Buitenwerf-van der Molen, God van vooruitgang: de popularisering van het modern-theologische gedachtegoed in Nederland (1857-1880)
}

(Hilversum, 2007), 34. 
from the pulpits." ${ }^{, 3}$ At that time, the Protestant pastor in Zaltbommel was J. G. R. Acquoy, a future professor of church history at Leiden University, who was wholeheartedly committed to the liberal cause and did not hesitate, indeed, to share his views with his congregation. ${ }^{4}$ More remarkable, however, was the case that Marx reported to Engels just a couple of months later. The Leiden Orientalist Reinhart Dozy had dared to publish a book in which he relegated the patriarchs Abraham, Isaac, and Jacob to the realm of fancy, portrayed the ancient Israelites as archaic idolaters, treated the first five books of the Bible as religious mythology, and on top of that equated the famous Black Stone of the Kaaba with a stone god originally worshipped by the Israelite tribe of Simeon. They write me from Holland, Marx added, "that the book has caused a great uproar among theologians there, particularly since Dozy is the most learned Dutch Orientalist - and a professor in Leiden to boot!"

The heated debate sparked by Dozy's book De Israëlieten te Mekka (The Israelites in Mecca, 1864) among Dutch and foreign scholars alike - German, French, and English voices quickly joined the discussion - was not only a theological dispute. Although both admirers and opponents treated the book as a specimen of modern Biblical criticism with implications

${ }^{3}$ Karl Marx to Friedrich Engels, 20 January 1864, in The Letters of Karl Marx, trans. Saul K. Padover (Englewood Cliffs, NJ, 1979), 177.

${ }^{4}$ J. G. R. Acquoy, Jezus Christus de waarheid: leerrede (Arnhem, 1863); idem, Jezus tegenover de ouden: leerrede (Arnhem, 1867). See also H. C. Rogge, "Johannes Gerardus Rijk Acquoy," Jaarboek van de Koninklijke Akademie van Wetenschappen gevestigd te Amsterdam 1897 (Amsterdam, 1898), 57-96, at 69-70.

${ }^{5}$ Marx to Engels, 16 June 1864, in Letters of Karl Marx, 186 (translation slightly modified). Marx's source of information was Leon Philips's letter of 12 June 1864, published in Jan Gielkens, Karl Marx und seine niederländischen Verwandten: eine kommentierte Quellenedition (Trier, 1999), 196-7. 
for the study of Islam, the debate was also an extensive reflection on the extent to which Dozy's bold suggestions and hazardous inferences were compatible with standards of serious scholarship. Dozy's book became a cause célèbre, well beyond academic circles, ${ }^{6}$ not merely because of its iconoclastic agenda, but also because a senior scholar with a well-established reputation for philological accuracy was suddenly being criticized, often in remarkably strong language, for violating elementary scholarly standards. Interestingly, Dozy's critics as well as his supporters discussed these standards almost invariably in terms of virtues and vices. Was Dozy a model of "frankness," as the Leiden Old Testament scholar Abraham Kuenen asserted? Or was Dozy guilty of "prejudice" and "dogmatism," as other critics maintained, because he adapted sources to his own purposes and hardly considered alternative interpretative strategies? Was his "shrewdness" to be applauded or did it come too close to "recklessness" and "rashness" to deserve endorsement? One wonders: What did these virtues and vices mean? And why were categories of virtue and vice so important in evaluating $D e$ Israëlieten te Mekka?

The Dozy affair has, of course, not gone unnoticed by historians of nineteenth-century Orientalism. Most notably, Ran HaCohen has examined how German-Jewish intellectuals responded to Dozy's provocative study, mapping their praise and blame for De Israëlieten te Mekka on a confessional map between "orthodoxy" and "liberalism."7 Additionally, Arnoud Vrolijk and Richard van Leeuwen have argued that personal factors, such as Dozy's fondness

\footnotetext{
${ }^{6}$ According to [W. G. C.] Byvanck, “R. Fruin (II)," De Gids, 63 (1899), II, i-xxxvi, at xxxi n.

1, Dozy's book was even prescribed to grammar school students.

${ }^{7}$ Ran HaCohen, Reclaiming the Hebrew Bible: German-Jewish Reception of Biblical

Criticism, trans. M. Engel (Berlin, 2010), 140-51.
} 
for polemics, fueled the debate no less than clashing political and religious agendas. ${ }^{8}$ None of these authors, however, have paid more than cursory attention to the language of virtue and vice that Dozy and his colleagues employed. From a disciplinary-historical perspective, this is perfectly understandable. The catalogues of virtues and vices on which Dozy's critics drew in evaluating De Israëlieten te Mekka are likely to reflect, in one way or another, the political, religious, and methodological fault lines that divided European Orientalists in the 1860s. These lines of division, in turn, have been extensively analyzed by Suzanne Marchand, Sabine Mangold, and others historians of nineteenth-century Orientalism. ${ }^{9}$ If the "shrewdness," “frankness," and "rashness" attributed to Dozy merely offer further illustrations of this by now familiar diversity - the "house divided against itself," as Robert Irwin calls it ${ }^{10}-$ historians of Orientalism have little reason to subject discourses of virtue and vice to special scrutiny.

If I embark on such a project nonetheless, I do so with the rather different purpose of making a methodological contribution to an emerging field of intellectual history known as "historical epistemology." Although this label can refer to different lines of inquiry, ${ }^{11}$ I follow

\footnotetext{
${ }^{8}$ Arnoud Vrolijk and Richard van Leeuwen, Arabic Studies in the Netherlands: A Short History in Portraits, 1580-1950, trans. Alastair Hamilton (Leiden, 2014), 97, 102.

${ }^{9}$ Suzanne L. Marchand, German Orientalism in the Age of Empire: Religion, Race, and Scholarship (Cambridge, 2009), 102-56; Sabine Mangold, Eine “weltbürgerliche Wissenschaft": die deutsche Orientalistik im 19. Jahrhundert (Stuttgart, 2004), 78-115. ${ }^{10}$ Robert Irwin, For Lust of Knowing: The Orientalists and Their Enemies (London, 2007), 189-236.

${ }^{11}$ As Uljana Feest and Thomas Sturm explain, historical epistemology has alternately been defined as the historical study of (1) epistemological concepts like objectivity, (2) epistemological objects like DNA, and (3) long-term scientific developments. Uljana Feest
} 
Lorraine Daston in understanding historical epistemology to be a form of intellectual history focused on "the history of categories that structure our thought, pattern our arguments and proofs, and certify our standards for explanation."12 Daston's study Objectivity, co-authored with Peter Galison, illustrates this line of research by examining in detail the changing meanings that nineteenth and twentieth-century scholars attributed to "objectivity." Daston historicizes this virtue by showing, among other things, that late nineteenth-century accounts of "mechanical objectivity" differed significantly from objectivity in an early nineteenthcentury sense of "truth to nature."13 Following Daston's example, other historians have examined what virtues such as "impartiality," "curiosity," and "humility" meant in different times and places. ${ }^{14}$ This contextualizing approach is a welcome challenge to the often rather

and Thomas Sturm, "What (Good) is Historical Epistemology?" Erkenntnis, 75 (2011), 285302 , at 288 .

${ }^{12}$ Lorraine Daston, "Historical Epistemology," in James Chandler, Arnold I. Davidson, and Harry Harootunian, eds., Questions of Evidence: Proof, Practice, and Persuasion across the Disciplines (Chicago, 1994), 282-9, at 282.

${ }^{13}$ Lorraine Daston and Peter Galison, Objectivity (New York, 2007).

${ }^{14}$ Kathryn Murphy and Anita Traninger, eds., The Emergence of Impartiality (Leiden, 2014); Sari Kivistö, The Vices of Learning: Morality and Knowledge at Early Modern Universities (Leiden, 2014). See also Kathryn M. Olesko, Physics as a Calling: Discipline and Practice in the Königsberg Seminar for Physics (Ithaca, NY, 1991), 366-450 on nineteenth-century virtues of exactitude. Histories of scholarly values, as distinguished from virtues and vices, can be found in M. Norton Wise, ed., The Values of Precision (Princeton, 1995) and Michael Hagner and Manfred D. Laubichler, eds., Der Hochsitz des Wissens: das Allgemeine als wissenschaftlicher Wert (Zurich, 2006). 
universal terms in which contemporary virtue epistemologists, among others, speak about the role of "epistemic virtues" in scholarly inquiry. ${ }^{15}$

Historicizing single virtues, however, is only a first step towards understanding what it meant for a scholar such as Dozy to be accused of "rashness" and "dogmatism" or to be praised for his "shrewdness" while simultaneously being criticized for "inaccurate" historical statements. Daston and her colleagues hardly if ever examine to what extent nineteenthcentury authors saw virtues as mutually dependent, in these sense that both the meaning and the relative significance of a virtue depended on those of other, complementary or contrasting ones. While Daston's historical epistemology convincingly shows that virtues must always be situated in time and place, it contributes only little to answering such questions as: How important was "accuracy" in relation to "fruitfulness"? To what extent did "impartiality" imply "transparency"? What was a "talent for conjecture" worth without "carefulness"? And was it regarded as legitimate for scholars to excel in some virtues (say, frankness) at the cost of others (say, precision) ${ }^{16}$

${ }^{15}$ On which see Jason Baehr, The Inquiring Mind: On Intellectual Virtues and Virtue Epistemology (Oxford, 2011) and John Greco and John Turri, eds., Virtue Epistemology: Contemporary Readings (Cambridge, MA, 2012).

${ }^{16}$ Although Daston and Galison admit that epistemic virtues may collide or otherwise stand in tension with each other, they suggest that such tensions are more likely to occur "at the level of specific, workaday choices" (Objectivity, 28) than on the ideal-typical level on which their study mostly operates. At the latter level, the primary form of tension that Daston encounters takes the form of friction between "old" and "new" ideals - between the ancient virtue of impartiality and the mid-nineteenth-century virtue of objectivity, for example. See Lorraine Daston, "Objectivity and Impartiality: Epistemic Virtues in the Humanities," in Rens Bod, 
These are no hypothetical questions. As I will argue in what follows, nineteenthcentury scholars such as Dozy's critics did not define their work in terms of single virtues, but conceived of scholarly performances in terms of weighing and balancing multiple virtues. The debate on Dozy's De Israëlieten te Mekka even suggests four ways in which virtues were seen as depending on each other. The extent to which scholars appreciated Dozy's "shrewdness" and "frankness" was dependent on (1) the degree in which Dozy practiced these virtues, (2) the extent to which they were kept in balance by other virtues, (3) the extent to which they were balanced by other scholars' virtues, and (4) the extent to which it was expected that they

would be balanced by future scholars' work. If this is, in one way or another, representative of how nineteenth-century scholars more generally conceived of virtues, vices, and their mutual relations, then historians have a good reason for abandoning the single virtue-focus that has dominated historical epistemology so far in favor of the broader, more open-ended question what sort of constellations of virtues scholars appealed to in defining scholarly standards and in evaluating each other's work. Historical epistemology may then enter a new phase in which balances, hierarchies, and other dependency relations between such virtues as "accuracy," "frankness," and "shrewdness" move to the center of attention.

\section{Dozy and his book}

Who, first of all, was the man who created such a stir with De Israëlieten te Mekka? ${ }^{17}$ Reinhart Dozy's biography conformed almost seamlessly to the narrative template of a Jaap Maat, and Thijs Weststeijn, eds., The Making of the Humanities, vol. 3 (Amsterdam, 2014), 27-41.

${ }^{17}$ On Dozy's life, see Johann Fück, Die arabischen Studien in Europa bis in den Anfang des 20. Jahrhunderts (Leipzig, 1955), 181-5; J. Brugman, "Dozy, a Scholarly Life According to Plan,” in Willem Otterspeer, ed., Leiden Oriental Connections, 1850-1940 (Leiden, 1989), 
nineteenth-century scholarly life. ${ }^{18}$ Born in 1820 , Dozy studied at Leiden University with the Arabic scholar Hendrik Engelinus Weijers. He won a golden medal of the Royal Institute at Amsterdam for his Dictionnaire détaillé des noms des vêtements chez les Arabes (1843, published in 1845) and obtained his Ph.D. degree in 1844 with a study on the Abbadid dynasty in Muslim Spain. Two years later, Dozy was made assistant curator of the collection of Oriental manuscripts in Leiden's university library (adiutor interpretis legati Warneriani). After publishing his Recherches sur l'histoire politique et littéraire de l'Espagne pendant le moyen âge in 1848, he was appointed to a special chair in "general history" at Leiden, which allowed Dozy to teach not only on his beloved medieval Spain, but also, following his fascination for all things French, on Napoleon and French poetry. ${ }^{19}$ In 1857 , he received a full professorship, which he kept until his death in 1883, shortly after the completion of a two-

62-81; Catrien G. Santing, "De middeleeuwen met een phrygische muts: de geschiedvisie van Reinart [sic] Dozy en Willem Jonckbloet,” Theoretische Geschiedenis, 26 (1999), 220-37; Vrolijk and Van Leeuwen, Arabic Studies, 95-102.

${ }^{18}$ On the discursive power of such biographical templates among mid-nineteenth-century scholars at Leiden, see Herman Paul, “'Werken zoo lang het dag is': sjablonen van een negentiende-eeuws geleerdenleven," in L. J. Dorsman and P. J. Knegtmans, eds., De menselijke maat in de wetenschap: de geleerden(auto)biografie als bron voor de wetenschaps- en universiteitsgeschiedenis (Hilversum, 2013), 53-73.

${ }^{19}$ See the lecture notes made by the future historian P. J. Blok, in Leiden University Library (hereafter: LUL), BPL 2982. Blok's opinions on these courses were not particularly favorable: "From a scholarly point of view, Dozy's entertaining historical lectures were a poor affair." Quoted in H. Brugmans, "Levensbericht van P. J. Blok," in Jaarboek der Koninklijke Akademie van Wetenschappen gevestigd te Amsterdam 1930-1931 (Amsterdam, 1931), 1-30, at 6 . 
volume Supplément aux dictionnaires arabes (1881). Together with Dozy's four-volume Histoire des Musulmans d'Espagne (1861), this is regarded as his best and most influential work. $^{20}$

These monographic studies as well as the source editions Dozy published - he undertook editions of Abdelwahid al-Marrakushi's history of the Almohades (1847) and Ibn Idhari's Al-Bayan al-Mughrib (1848-1851), among other titles - testify to the "philological ethos" that dominated the study of history, languages, and religion in mid-nineteenth-century Leiden. It was an ethos in which source criticism stood in higher regard than historical synthesis, accuracy counted as more important than originality, and a healthy skepticism, especially vis-à-vis traditional authority, was seen as the beginning of all wisdom ("I am nothing if not critical" was a favorite Shakespeare quotation in nineteenth-century Leiden). ${ }^{21}$

${ }^{20}$ The influential German Orientalist Heinrich Leberecht Fleischer reviewed Dozy's work in great detail in his “Studien über Dozy’s Supplément aux dictionnaires arabes” (1881-6), in Fleischer, Kleinere Schriften, vol. 2 (Leipzig, 1888), 470-781 and vol. 3 (Leipzig, 1888), 1102. According to M. J. de Goeje, "Levensbericht van Reinhart Dozy," in Jaarboek van de Koninklijke Akademie van Wetenschappen gevestigd te Amsterdam voor 1883 (Amsterdam, [1884]), 12-52, at 47, Dozy was particularly satisified with Fleischer's praise.

${ }^{21}$ Herman Paul, “The Scholarly Self: Ideals of Intellectual Virtue in Nineteenth-Century Leiden," in Rens Bod, Jaap Maat, and Thijs Weststeijn, eds., The Making of the Humanities, vol. 2 (Amsterdam, 2012), 397-411. The line from Shakespeare's Othello was approvingly quoted by the historian Robert Fruin in his Afscheidsrede bij het nederleggen van het hoogleeraarsambt aan de Rijksuniversiteit te Leiden, den 1sten juni 1894 uitgesproken (The Hague, 1894), 28 and attributed to Abraham Kuenen by C. P. Tiele, Elements of the Science of Religion, vol. 1 (Edinburgh, 1897), 17. The term "philological ethos" is borrowed from Rainer Kolk, "Wahrheit, Methode, Charakter: zur wissenschaftlichen Ethik der Germanistik 
Dozy's source editions also furnished the author with a solid reputation among European Arabists. Such a reputation mattered, because trust played an important role in philological scholarship. To no small degree, scholars guaranteed the reliability of a transcript or an inference with their own good name. ${ }^{22}$ This explains why Dozy's reputation was frequently invoked in the debate prompted by De Israëlieten te Mekka, as a reason why the book generated much interest, ${ }^{23}$ as a guarantee that it could not be entirely wrong-headed, ${ }^{24}$ as a reason why it deserved serious study, ${ }^{25}$ or as a cause of surprise (that "a man of such first-rate manly learning" was able to produce such “wild, youthful leaps and bounds"). ${ }^{26}$ Dozy’s reputation was also seen as deserving respectful treatment. Thus, when the German rabbi im 19. Jahrhundert," Internationales Archiv für Sozialgeschichte der deutschen Literatur, 14 (1989), 50-73, who in turn derives it from Franz Schultz, "Die Entwicklung der Literaturwissenschaft von Herder bis Wilhelm Scherer," in Emil Ermatinger, ed., Philosophie der Literaturwissenschaft (Berlin, 1930), 1-42, at 37.

${ }^{22}$ Kasper Risbjerg Eskildsen, "Inventing the Archive: Testimony and Virtue in Modern Historiography," History of the Human Sciences, 26/4 (2013), 8-26, at 9-11; Steven Shapin, A Social History of Truth: Civility and Science in Seventeenth-Century England (Chicago, 1994), 65-125.

${ }^{23}$ J. C. Matthes, “Eene nieuwe ontdekking,” De Tijdspiegel (1864), II, 349-69, at 349.

${ }^{24}$ [Aloys Sprenger], review in Das Ausland, 37 (1864) 773-6, at 773 and, in almost identical wording, the anonymous review in The Methodist Quarterly Review, 48 (1865), 120-1, at 121. ${ }^{25}$ [Gustav Weil], review in Heidelberger Jahrbücher der Literatur, 57 (1864), 595-602, at 596.

${ }^{26}$ [Petrus Hofstede de] G[root], "De oorsprong van de Mohamedaansche godsdienst," Waarheid in Liefde (1865), 373-6, at 373. See also M. Jastrow's review in the Monatsschrift für Geschichte und Wissenschaft des Judenthums, 13 (1864), 313-17, at 314. 
Ludwig Philippson expressed his doubts about the soundness of Dozy's mind after reading $D e$ Israëlieten te Mekka, ${ }^{27}$ the German-Jewish scholar Raphael Kirchheim rebuked him, under reference to the author's reputation, not to write "in such a rejecting, dismissive tone" about the famous Dutch Orientalist, "as if he has was dealing with one of the savants of the Mainzer Kladderadatsch.,"28

Philological virtuosity, however, was only one aspect of Dozy's reputation. Like many of his generation, Dozy was "caught between romanticism and historicism, between its grand political and aesthetic dreams and its desire to be counted wissenschaftlich." 29 Despite his commitment to the minuteness and exactness favored by the philological ethos, Dozy preferred to model himself after such Romantic French historians as Prosper de Barante and Augustin Thierry. He also valued a well-polished writing style over masses of learned footnotes and did not shrink, to the astonishment of some of his Leiden colleagues, from using poetry as an historical source. ${ }^{30}$ Additionally, Dozy had a sharp tongue, judging by his letters, some of which were punctuated with Arabic curses, ${ }^{31}$ and by his sometimes ruthlessly critical

${ }^{27}$ [Ludwig Philippson], review in Allgemeine Zeitung des Judenthums, 28 (1864), 589-90, at 589.

${ }^{28}$ Raphael Kirchheim, review in Ben Chananja, 7 (1864), 974-7 and 1000-01, at 975. The Kladderadatsch (1848-1944) was a German satirical periodical.

${ }^{29}$ Marchand, German Orientalism, 138.

${ }^{30}$ Santing, "Middeleeuwen," 221, 225; Brugman, "Dozy," 72.

${ }^{31}$ Manuela Marín, "Scholarship and Criticism: The Letters of Reinhart Dozy to Pascual de Gayangos (1841-1852)," in Cristina Alvarez Millán and Claudia Heide, eds., Pascual de Gayangos: A Nineteenth-Century Spanish Arabist (Edinburgh, 2008), 68-85, at 85 n. 52. 
reviews, through which he alienated several colleagues near and abroad. ${ }^{32}$ In his Recherches, most notably, Dozy lashed out so harshly at the Spanish Orientalist José Antonio Conde that he acquired the dubious reputation of being "a merciless controversialist.", 33

The proverbial whirlwind that Dozy had to reap after this wind came with $D e$ Israëlieten te Mekka. This book emerged out of Het islamisme (Islamism, 1863), a popular introduction to the history of Islam that Dozy contributed to a series on "The Most Important Religions" published by A. C. Kruseman. ${ }^{34}$ During his preparations for this work of synthesis, Dozy arrived at what he called revolutionary insights into the origins of Islam. As he wrote Kruseman, his publisher, in November 1862: "The result at which I have now arrived is, I think, rather surprising, also for Biblical theology; it is also important, because it puts the origin of Islam in a new light. ${ }^{, 35}$ Although in Het islamisme, Dozy did not yet present his changed views, he promised his readers a more detailed exposition of what he had discovered:

In this way, I have obtained a result that has utterly surprised me, but that cannot be communicated in just a few pages, given that it is closely related to many other, arguably even more important results; it is entirely at odds with reigning views; it

\footnotetext{
${ }^{32}$ See, e.g., ibid., 79-80; LUL, BPL 2487, P. J. Veth to Dozy, 10 December 1843 and 3 January 1846.

${ }^{33}$ Irwin, For Lust of Knowing, 175. See also Brugman, "Dozy," 66; Daniël van der Zande, "Martinus Th. Houtsma, 1851-1943: een bijdrage aan de geschiedenis van de oriëntalistiek in Nederland en Europa" (Ph.D. thesis, Utrecht University, 1999), 129; Vrolijk and Van Leeuwen, Arabic Studies, 95-7.

${ }^{34}$ On this series: Arie L. Molendijk, The Emergence of the Science of Religion in the Netherlands (Leiden, 2005), 62-3.

${ }^{35}$ LUL, LTK 1505, Dozy to A. C. Kruseman, 26 November 1862.
} 
sounds very strange, and given that in the realm of scholarship no one can demand to be taken on his word, it requires a lengthy, scholarly demonstration of proof... ${ }^{36}$

Dozy's closest pupil, Michaël Jan de Goeje, who followed the project from nearby, had the exciting feeling of accompanying a discoverer: "Almost every day brought something new. Everywhere new perspectives revealed themselves, one riddle after another came to a solution. ${ }^{, 37}$ Also, Dozy's correspondence shows that colleagues impatiently begged for quick dispatch of the results. ${ }^{38}$ When these were eventually published, De Goeje declared in superlatives: "In this book, we receive a series of revelations regarding the darkest and most enigmatic issues; it provides a key to penetralia on which one had never hoped to behold; it has removed obstacles that one perceived to be insurmountable as if by magic." 39

\footnotetext{
${ }^{36}$ R. Dozy, Het islamisme (Haarlem, 1863), 2.

${ }^{37}$ De Goeje, "Levensbericht van Reinhart Dozy,” 37-8.

${ }^{38}$ LUL, BPL 2487, Abraham Geiger to Dozy, 16 June 1864 and undated (1864). Writing to Michaël Jan de Goeje, Theodor Nöldeke adopted a more reserved stance: "Between the two of us, I have to admit that I do not expect much of the new discoveries that have been promised." LUL, BPL 2389, 1 May 1864 (I owe this reference to Christiaan Engberts).

${ }^{39}$ M. J. de Goeje, “Een stap vooruit,” De Gids, 28 (1864), II, 297-312, at 298. Dozy himself spoke in no less exalted prose about "an entire series of discoveries, of a kind I had never made before and had never dared to hope for; discoveries that I trust will receive an honorable place among the great scholarly results achieved in this century, which shall break new grounds in philology, the history of humankind, and the history of religion. I have literally received inspirations, I myself don't know how.” LUL, LTK 1505, Dozy to Kruseman, 26 November 1862.
} 
Dozy's most revolutionary hypothesis was that the Kaaba stone in Mecca had originally been an ancient Israelite stone god that the Israelite tribe of Simeon had exported to Arabia in the days of king Saul. On etymological grounds, Dozy supposed that the famous "Meccan festival" had been established by these Simeonites after the example of the Baal feasts in ancient Israel, long before the introduction of Jewish monotheism in the time of Ezra. If ancient tradition was right to identify the Baal in Mecca with a stone in a hole, then Dozy believed this to correspond almost neatly to Israel's ancient history. For in Dozy's view, Abraham and Sarah had not been historical figures, but Hebrew designations for "stone" and "hole," respectively, referring to a stone god and the pit in which this deity resided. The Leiden professor had no difficulty explaining why Genesis personified this stone and this pit into a patriarch and matriarch: this had been the work of editors in the days of Ezra, who rejected such a primitive stone worship from the monotheistic perspective to which Israel had converted after the Babylonian exile. Accordingly, for Dozy, the entire ancient history of Israel, as described in the Pentateuch, had been an invention of tradition by "Ezra and his helpers." 40

\section{An international debate}

Although some of Dozy's speculative conjectures raised many an eyebrow, it was actually not very surprising to find a Leiden professor in the 1860s applying techniques of modern Biblical criticism to questions related to the origins of Islam. First of all, by 1864, the Leiden theological faculty had a reputation for being at the forefront of Old Testament scholarship. It was here that students from all over the world came to study with Abraham Kuenen, whose work contributed significantly to the "documentary hypothesis" often associated with the

\footnotetext{
${ }^{40} \mathrm{R}$. Dozy, De Israëlieten te Mekka van Davids tijd tot in de vijfde eeuw onzer tijdrekening (Haarlem, 1864), 8.
} 
names of Karl Heinrich Graf (on whom more below) and Julius Wellhausen (a great admirer of Kuenen). ${ }^{41}$ For much the same reason, orthodox Calvinists in the Netherlands as well as abroad distrusted all that came from Leiden, lamenting the faculty's betrayal of Reformed orthodoxy. ${ }^{42}$ As a former South African student reported back to Kuenen in 1863: "For me, my stay in Leiden has become a cause of much sorrow. . . . Even before my return to the Cape, I had acquired the reputation of being an heretic teacher [dwaalleeraar]." ${ }^{43}$ Secondly, by the early 1860 s, the origins of Islam had been capturing the fascination of Orientalists for some decades already, as evidenced by Abraham Geiger's and Gustav Weil's much-discussed studies in this area. ${ }^{44}$ Of crucial importance, however, was the 1860 publication of Theodor Nöldeke's Geschichte des Qorâns. Building on Geiger and Weil, among others, Nöldeke radicalized their "historical-critical" treatment of the Islamic holy book by separating Medinaera and Mecca-era texts as radically as Old Testament scholars distinguished between "J"

${ }^{41}$ P. B. Dirksen and A. van der Kooij, eds., Abraham Kuenen (1828-1891): His Major Contributions to the Study of the Old Testament: A Collection of Old Testament Studies Published on the Occasion of the Centenary of Abraham Kuenen's Death (10 December 1991) (Leiden, 1993).

${ }^{42}$ E.g., Is. da Costa, Wat er door de theologische faculteit te Leyden al zoo geleerd en geleverd wordt: eene stem der smart en des beklags (Amsterdam, 1857); "Leydsche beginselen," De Tijdspiegel (1862), II, 393-408.

${ }^{43}$ LUL, BPL 3028, Johannes Jacobus Kotzé to Abraham Kuenen, 20 November 1863.

${ }^{44}$ On Geiger's and Weil's Koranforschung, see Susannah Heschel, Abraham Geiger and the Jewish Jesus (Chicago, 1998), 50-75 and Ruchama Jerusha Johnston-Bloom, "Oriental Studies and Jewish Questions: German-Jewish Encounters with Mohammed, the Qur'an, and Islamic Modernities” (Ph.D. thesis, University of Chicago, 2013), 85-125. 
(Jahwist) and "P" (Priestly Code) elements in the Pentateuch. ${ }^{45}$ Dozy repeatedly referred to this book, most notably in Het islamisme from $1863 .^{46}$ It is this combination of factors that helps explain why a book like De Israëlieten te Mekka could emerge from Leiden's theological faculty: its theme was timely and its method consistent with Biblical studies as practiced by Kuenen.

Given the contested character of both, it is also not surprising that, as Marx correctly noticed, De Israëlieten te Mekka drew response from far and wide, often in the form of journal articles that sometimes ran to dozens of pages. ${ }^{47}$ Authors with a penchant for dramatic generalization used Dozy's book as an occasion for lament over the sorry state of modern science, Leiden Oriental scholarship, or liberal theology in the Netherlands, while others, more focused on the sum and substance of Dozy's arguments, wrote lengthy reviews to subject one or more of Dozy's ideas to critical scrutiny. Judging by translations that appeared both in the Netherlands and abroad, some of these pieces reached a readership beyond the

${ }^{45}$ Emmanuelle Stefanidis, “The Qur'an Made Linear: A Study of the Geschichte des Qorâns' Chronological Reordering,” Journal of Qur'anic Studies, 10 (2008), 1-22; Nicolai Sinai, "Orientalism, Authorship, and the Onset of Revelation: Abraham Geiger and Theodor Nöldeke on Muhammad and the Qur'ān," in Dirk Hartwig et al., eds., "Im vollen Licht der Geschichte”: die Wissenschaft des Judentums und die Anfänge der kritischen Koranforschung (Würzburg: Ergon, 2008), 144-54.

${ }^{46}$ Dozy, Islamisme, 18, 31 n. 2, 75.

${ }^{47}$ Judging by his letters to Kruseman (LUL, LTK 1505, 24 August 1864; 3, 6, and 19 September 1864; 17 October 1864; 13 November 1864) and De Goeje (LUL, BPL 2389, 11 October 1864), Dozy monitored with great attention how colleagues from near and abroad responded to this book. 
academy. The highly critical response by Heinrich Ewald, "the pope of Göttingen," 48 for example, almost immediately appeared in Dutch translation, while John William Colenso, the Bishop of Natal who in the mid-1860s was engaged in bitter controversy over his own contributions to Biblical scholarship, kept an English-language audience informed with a translation of Henricus Oort's brochure De dienst der Baälim in Israël (The Worship of Baalim in Israel, 1864). ${ }^{49}$ The most widely discussed response, in the Netherlands as well as abroad, was a long review by Karl Heinrich Graf, the German Old Testament scholar, who issued the devastating judgment that Dozy's research, "carried out with so much acuteness and learning," had a scholarly worth of "nothing, absolutely nothing." ${ }^{, 50}$ Both the German original and the Dutch translation of this review were frequently quoted. ${ }^{51}$

\footnotetext{
${ }^{48}$ M. J. de Goeje, “Bibliographisch album,” De Gids, 29 (1865), I, 531-48, at 531.

${ }^{49}$ H. Oort, The Worship of Baalim in Israel: Based Upon the Work of R. Dozy, "The Israelites at Mecca," trans. John William Colenso (London, 1865). On Colenso's interest in Dozy, see LUL, BPL 3028, Colenso to Abraham Kuenen, 3 February 1865; George W. Cox, The Life of
} John William Colenso, D. D., Bishop of Natal, vol. 1 (London, 1888), 223-5. In order to reach an international audience, the publisher also issued a German translation, which became a commercial disaster. In twelve years' time, only 251 out of 1,500 copies were sold (J. W. Enschedé, A. C. Kruseman, vol. 2 [Amsterdam, 1902], 99-100). Nonetheless, the German edition contributed to the international reputation of Dozy's work, witness the fact that not only German, but also English-language reviews such as those in The Westminster Review, 26 (1864), 484 and The Saturday Review, 18 (1864), 372 based themselves on Die Israeliten zu Mekka.

${ }^{50}$ K. H. Graf, review in Zeitschrift der Deutschen Morgenländischen Gesellschaft, 19 (1865), 330-51, at 350. See also K. H. Graf to Eduard Reuss, 6 October 1864 and 6 May 1866, in K. 
At first sight, the debate over De Israëlieten te Mekka seemed to develop more or less along confessional lines. Thus, words of appreciation and admiration came primarily from the liberal side, that is to say, from authors who expected Biblical scholars to treat the Old and New Testaments in the same way that an ancient philologist would treat the Iliad or Odyssey: with historical questions, philological methods, and a sound amount of skepticism vis-à-vis everything resembling myth or legend. It was no accident that many of these sympathizers had been trained or were employed at Leiden's theological faculty. Even if these authors had not necessarily been accustomed to scholarly iconoclasm during their Leiden student years, they had all appropriated, in smaller or larger degrees, an ethos in which candid questions and bold hypotheses did not count as bad things per se. Apart from that, one suspects that the

Budde and H. J. Holtzman, eds., Eduard Reuss' Briefwechsel mit seinem Schüler und Freunde Karl Heinrich Graf (Giessen, 1904), 538, 564.

${ }^{51}$ E.g., A. Kuenen, “Simeonieten en Ismaëlieten: eene bijdrage tot de critiek van Dozy’s Israëlieten te Mekka," Godgeleerde Bijdragen, 40 (1866), 449-515, at 449; X+Y [pseudonym of Meijer Roest Mzn.], “Boekbeschouwing,” Nieuw Israëlietisch Weekblad (1 September 1865); H. Pierson, Baetyliëndienst (Arnhem, 1866), 45-7; Philip Elte, Moderne theologie in Nederland (Amsterdam, 1871), 8-9. According to HaCohen, Reclaiming the Jewish Bible, 145 n. 34, the seven-part series of articles published under the pseudonym " $\mathrm{X}+\mathrm{Y}$ " in the Nieuw Israëlietisch Weekblad was authored by Joseph Hirsch Dünner, the future chief rabbi of the Dutch Israelite Main Synagogue. M. Roest Mzn., "Brieven van een provinciaal over de Amsterdamsche opperrabbinaats-questie,” Nieuw Israëlietisch Weekblad (10 April 1874) reveals, however, that the first three articles were written by Meijer Roest, assistant librarian of the Royal Academy of Sciences and editor of the Nieuw Israëlietisch Weekblad. The remaining four articles came from Dünner's pen. 
appreciation that these Leiden scholars and alumni expressed for Dozy and his work reflected their personal acquaintance with the Orientalist. ${ }^{52}$

Criticism, by contrast, came primarily from Calvinists in the Netherlands Reformed Church as well as from orthodox Jews in both the Dutch and German language realms. The Reformed pastor H. A. Leenmans, for example, translated Graf's critical review into Dutch in order to contribute, in his own words, to a battle against "a falsely named scholarship [eene valschelijk genaamde wetenschap]" that did not shrink from laying violent hands on God's holy Word. ${ }^{53}$ The revivalist magazine De Heraut also recommended this review, because Graf's judgment nicely illustrated "how men of scholarship [wetenschap] in Germany treat the sort of products that are adored in this country with frantic applause..."54 Lambertus Tinholt, a Reformed pastor in Haarlemmermeer, even tried to produce a reductio ad absurdum of Dozy's critical method with an humorous parody that exposed Charles V as a fictional character and suggested a new dating for the entire Greek and Roman literary canon, which Erasmus was said to have fabricated on the base of Aztec sources - complete with turns of phrases that seemed to have walked right out of Dozy's book ("These assertions are

\footnotetext{
${ }^{52}$ See esp. J. P. N. Land, "Een nieuwe lichtstraal op het Oude Verbond," De Nederlandsche Spectator (1864), 227-9; Matthes, "Nieuwe ontdekking"; H. Oort, De dienst der Baälim in Israël: naar aanleiding van het geschrift van dr. R. Dozy "De Israëlieten te Mekka” (Leiden, 1864). Land, Matthes, and Oort had defended their doctoral dissertations at Leiden in 1854 , 1859, and 1860, respectively. Another enthusiastic (anonymous) review appeared in the liberal periodical, De Onderzoeker, 6 (1865), 129.

${ }^{53}$ H. A. Leenmans, “Aan den lezer,” in De Israëlieten te Mekka van dr. R. Dozy, beoordeeld door dr. K. H. Graf, trans. H. A. Leenmans (Utrecht, 1866), iii-iv, at iv.

${ }^{54}$ De Heraut (6 October 1865), as cited in Enschedé, Kruseman, vol. 2, 97-8.
} 
strange, but I will demonstrate that they are not unfounded"). ${ }^{55}$ As Ran HaCohen has pointed out, the praise and blame of German-Jewish reviewers also showed a clear correlation to their position in the spectrum between orthodoxy and Reformjudentum. ${ }^{56}$

This confessional topography, however, offers only a partial explanation of the variety of responses that Dozy's book elicited. Despite their common liberal agenda, theologians such as Kuenen, Oort, J. P. N. Land, and J. C. Matthes judged De Israëlieten te Mekka very differently. This divergence was not only caused by philological differences of insight (how plausible was it to read the Hebrew baalath-beer as baal-habeer?). At least as decisive were different assessments of the virtues that scholars were supposed to display in their work. How important, for instance, was the boldness that Dozy had exhibited by proposing, in Kuenen's words, "a complete revolution in the field of Old Testament studies"? ${ }^{57}$ And how did this frankness relate to the accuracy and reliability required by the philological ethos?

\section{Dozy's virtues}

${ }^{55}$ L. Tinholt, "Eene Jakoetische voorlezing uit de 38ste eeuw onzer jaartelling," Stemmen voor Waarheid en Vrede, 1 (1864), 411-44, at 416. The Athenaeum, too, chose for ridicule by presenting Dozy's book as a clever joke ("a rare hoax" and "brilliant travesty") and the serious responses it elicited as giving Dozy lots of fun: The Athenaeum (1865), II, 797-99, at 797. (I have been unable to identify the author of this piece.) Colenso objected to this treatment in J. W. Natal, "Israelites in Mecca," The Athenaeum (1866), I, 497-8. Cf. Colenso to Charles Lyell, 1 March 1866, in George W. Cox, The Life of John William Colenso, D. D., Bishop of Natal, vol. 2 (London, 1888), 22.

${ }^{56}$ HaCohen, Reclaiming the Hebrew Bible, 145.

57 A. Kuenen, “De Baälsdienst onder Israël," Godgeleerde Bijdragen, 38 (1864), 449-91, 449. 
Although Dozy's critics had many grounds for disagreeing with each other, they shared at least one conviction: Dozy's argument was "very ingenious." ${ }^{, 58}$ Friends and foes alike praised Dozy's "shrewdness" (scherpzinnigheid in Dutch or Scharfsinn in German) - the first of three virtues that were frequently referred to in the debate. ${ }^{59}$ No matter how they evaluated Dozy's revisionist dating of the Pentateuch or his etymology of "Abraham" and "Sarah," almost all participants in the debate agreed that the author had a "sharp eye" and that he excelled in “sagacity," "sound criticism," and "penetration." ${ }^{60}$ Philologically oriented historians often presented this virtue of shrewdness as a necessary condition for critical source examination: it was considered indispensable for disentangling layers of meaning in historical texts and for unraveling textual dependencies. ${ }^{61}$ Although shrewdness could, of course, overstep its bounds - some scholars warned against the danger of excessive, "hair-splitting shrewdness,"62 just as others worried that "criticism" could degenerate into "hyper-criticism",63 - it was regarded as a key virtue, provided the right dose was maintained.

${ }^{58}$ John William Colenso, The Pentateuch and Book of Joshua Critically Examined, vol. 5 (London, 1865), 265. See also The Saturday Review, 16 (1864), 372.

${ }^{59}$ De Goeje, "Stap vooruit," 301; Kuenen, "Baälsdienst onder Israël," 480; Matthes, “Nieuwe ontdekking,” 364. Along similar lines: Godgeleerde Bijdragen, 38 (1864), 350-1, at 350 and Historische Zeitschrift, 13 (1865), 270-2, at 272.

${ }^{60}$ Matthes, "Nieuwe ontdekking," 351; N. de Khanikoff, review in Journal Asiatique, 4 (1864), 433-49, 433.

${ }^{61}$ Ernst Bernheim, Lehrbuch der historischen Methode: mit Nachweis der wichtigsten Quellen und Hülfsmittel zum Studium der Geschichte (Leipzig, 1889), 296-7.

${ }^{62}$ Ernst Bernheim, Geschichtsforschung und Geschichtsphilosophie (Göttingen, 1880), 71.

${ }^{63}$ See, e.g., "Rinck dritter Brief Pauli an die Corinther," Heidelberger Jahrbücher der Literatur, 16 (1823), 529-44, at 535; Christian Kapp, Über den Ursprung der Menschen und 
This applies to a lesser extent to a second quality that was ascribed to Dozy: the "talent for conjecture" (gave van combinatie) that allowed scholars to discern patterns in their source material and to make a story out of them. ${ }^{64}$ Both Kuenen and Graf praised Dozy's "gift for conjecture" (Combinationsgabe) and "ability to conjure" (Combinationsfertigkeit $)^{65}-$ an ability that "organizes the data into fruit-bearing results," as the German historian Ernst Bernheim would explain in his Lehrbuch der historischen Methode (1889). ${ }^{66}$ Unlike shrewdness, which was primarily regarded as important for source criticism, this talent for conjecture was regarded as needed especially for what Bernheim called "interpretation" (Auffassung): the formulation of hypotheses and the making of causal inferences. Not everyone, however, was equally charmed by this aspect of historical scholarship. Influenced by the philological ethos that made its impact felt also on the German Altertumswissenschaften ${ }^{67}$ some held that "interpretation" was not possible before "criticism" had done its work. Hypotheses, moreover, required a "creative intuition" that was difficult to codify by methodological means and therefore sat relatively uncomfortably with a view of

Völker, nach der mosaischen Genesis (Nuremberg, 1829), 193; Karl August Credner, Einleitung in das Neue Testament, vol. 1 (Hall, 1836), 338 or, in the Netherlands, [R. C. Bakhuizen van den Brink], “Kritiek, hyperkritiek, onkritiek: nalezingen op Labruyères Des ouvrages de l'esprit," De Gids, 3 (1839), 476-83, 513-22.

${ }^{64}$ [Hofstede de] G[root], “Oorsprong van de Mohamedaansche godsdienst,” 373.

${ }^{65}$ Kuenen, "Baälsdienst onder Israël," 480; Graf, review, 331.

${ }^{66}$ Bernheim, Lehrbuch der historischen Methode, 430.

${ }^{67}$ See Ulrich Muhlack, “Historie und Philologie,” in Muhlack, Staatensystem und Geschichtsschreibung: ausgewählte Aufsätze zu Humanismus und Historismus, Absolutismus und Aufklärung, ed. Notker Hammerstein and Gerrit Walther (Berlin, 2006), 142-72. 
scholarship that put a premium on methodological control. ${ }^{68}$ Praise for Dozy's "talent for conjecture" therefore amounted to taking a stance in debates over the nature and priorities of geisteswissenschaftliche research.

The joy with which Hendrik Pierson, a Reformed pastor in Heinenoord, welcomed De Israëlieten te Mekka provides a telling example of this. In Pierson's assessment, the priority that Biblical scholars had long been assigning to "criticism" had led to an overabundance of negative results:

she made everything empty, barren, many a flower she had torn apart, many an illusion she had destroyed and even though we had to endorse that she eradicated foreign plants, which had been proven not to be at home in the garden, we did not receive anything in return and witnessed how everything was gradually turned into a wasteland. $^{69}$

Consequently, "our soul thirsts for positive results," as Pierson wrote with an allusion to Psalm 42. Even if Dozy's hypotheses turned out not to be correct, it was a relief so see a senior scholar mustering the courage to draw firm lines through the ancient history of Israel. ${ }^{70}$ Accordingly, a third virtue attributed to Dozy was "frankness" (vrijmoedigheid) or “boldness” (koenheid). Dozy’s “bold hypothesis,” wrote Kuenen in 1870, six years after publication of De Israëlieten te Mekka, had provided a "salutary shock" to many in the fields

\footnotetext{
${ }^{68}$ Bernheim, Lehrbuch der historischen Methode, 430.

${ }^{69} \mathrm{H}$. Pierson, De heilige steenen in Israël: naar aanleiding van het boek van prof. R. Dozy:

“De Israëlieten te Mekka” (Rotterdam, 1864), 6.

${ }^{70}$ Ibid., 7.
} 
of Biblical and Oriental studies and stimulated a greater amount of "frankness." "71 In Kuenen's vocabulary, "frankness" could mean two things. On the one hand, it was the courage required for launching a hypothesis in the absence of indisputable proofs or logically compelling inferences. ${ }^{72}$ On the other, it was the bravery to defy the power of religious traditions ${ }^{73}-$ a virtue that Kuenen appreciated not only in Dozy, but also in Colenso, who in spite of much opposition published one critical study of the Pentateuch after another. ${ }^{74}$ Likewise, the Amsterdam philosopher and Orientalist Jan Pieter Nicolaas Land characterized Dozy as a "stout-hearted" (stoute) scholar, who like a brave general "ventures a campaign deeply into a country of which he possesses only very general maps." ${ }^{, 75}$

Land realized that not every reader would classify this daredevilry as a virtue conducive to historical understanding. He therefore added that Dozy's deficiencies were nothing but "les défauts de ses qualités": every achievement, after all, comes with a price. ${ }^{76}$ This price, however, divided Dozy's critics, too. Each of the three virtues mentioned so far was contested, although on different grounds. In the Jewish Nieuw Israëlietisch Weekblad (New Israelite Weekly), the future Amsterdam chief rabbi Joseph Hirsch Dünner, for example, agreed that Dozy's criticism was ingenious. He added, however, that Dozy had not been critical enough, given that he had disregarded the "first requirements of true criticism,"

${ }^{71}$ A. Kuenen, "Critische bijdragen tot de geschiedenis van den Israëlietischen godsdienst," Theologisch Tijdschrift, 4 (1870), 391-426, at 406.

${ }^{72}$ A. Kuenen, De godsdienst van Israël tot den ondergang van den Joodschen staat, vol. 2 (Haarlem, 1870), 27, 173, 214, 272, 311, 428, 537.

${ }^{73}$ Ibid., 521.

${ }^{74}$ A. Kuenen, John William Colenso (Haarlem, 1884), 11-12.

${ }^{75}$ Land, "Nieuwe lichtstraal," 229.

${ }^{76}$ Ibid. 
namely a thorough knowledge of the Hebrew language. ${ }^{77}$ Apparently, criticism could be practiced in different degrees, so that the question was not whether Dozy was critical, but to what extent he was so. Secondly, more did not always count as better. Kuenen, for instance, warned that "frankness" could easily turn to "recklessness."78 This shows that the Old Testament scholar was indebted to an Aristotelian understanding of virtue as a juste milieu between two vices - cowardice and recklessness in the case of frankness. In this line of thought, it was not sufficient to observe that Dozy displayed shrewdness, a talent for conjecture, and frankness or boldness. Decisive was rather the question whether he practiced these virtues to an extent that prevented them from degenerating into vices.

\section{Dozy's vices}

This brings us to the storm of criticism that De Israëlieten te Mekka elicited. Whereas scholarly praise was often formulated in terms of virtues, critics usually focused on vices. And whereas supporters frequently spoke in terms of "light" and "darkness" - about the dark

${ }^{77} \mathrm{X}+\mathrm{Y}$ [pseudonym of Joseph Hirsch Dünner], “Boekbeschouwing,” Nieuw Israëlietisch Weekblad (29 December 1865). Similar complaints about modern historians who turned out not to as "critical," "impartial," or "truth-loving" as they claimed to be were frequently issued among orthodox Protestants in fear of modern Biblical criticism and among Roman Catholics whose views of the pope, the church, or the saints were put to scrutiny by modern, critical historians. See, for instance, the Roman-Catholic responses to the liberal Dutch historian Robert Fruin in [Herman] Schaepman, "Een nieuw verwijt uit een oude doos," De Wachter, 2 (1872), II, 26-47, at 35; W. F. N. van Rootselaar, "De geschiedschrijver prof. dr. R. Fruin," De Katholiek, 109 (1896), 26-62, at 35 and 48-50; ibid., "De geschiedschrijvers: Ranke en Fruin,” De Katholiek, 110 (1896), 180-96, at 196.

${ }^{78}$ Kuenen, "Critische bijdragen," 406. 
origins of Islam, for instance, which Dozy's book supposedly helped clarify ${ }^{79}$ - opponents preferably employed architectural metaphors. They called De Israëlieten te Mekka an assemblage of "groundless" or "unfounded" hypotheses, an edifice without proper foundations, or a vault resting on "such mutually supporting rib stones . . . that the most profitable lesson one can draw from the book is how dangerous such edifices are." ${ }^{, 0}$ In Graf's wording:

Everyone else would regard the results that are presented here with great confidence as indisputably proven historical facts as a web of light-hearted hypotheses, daring and adventurous inferences and conjectures, and be surprised at the rashness with which the most far-reaching conclusions are often drawn from unproven assumptions ... Everything floats in the air, nothing rests on a firm, scholarly smoothed ground, everywhere the lack of solid critical rules is manifested in a most strident manner. ${ }^{81}$

${ }^{79}$ De Goeje, "Stap vooruit,” 298; Matthes, "Nieuwe ontdekking,” 349-51; Oort, Dienst der Baälim, 2, 55; LUL, BPL 2487, William McGuckin de Slane to Reinhart Dozy, 3 February 1865.

${ }^{80}$ Ewald, review, 1270; C. H. van Herwerden CHz., "Over de steenen- en boomendienst van Israël," Waarheid in Liefde (1865), I, 377-98, at 378 and 379; Moritz Steinschneider, review in Hebraeische Bibliographie, 7 (1864), 103-06, at 105. See also Heinrich Leberecht Fleischer to Michaël Jan de Goeje (LUL, BPL 2389, 5 December 1865): "Dear Mister Doctor, I honestly admit to you that I consider these inferences - but entirely between the two of us! learned Calembourgs [word plays], on which an historical edifice cannot be erected." ${ }^{81}$ Graf, review, 350 . 
As this diatribe illustrates, "rashness" (lichtvaardigheid) or "levity" (lichtzinnigheid) was the first vice that was held responsible for the fragility of Dozy's edifice. According to Ewald, Dozy's lack of serious study was evidenced by the "vast number of continuously new and continuously more far-reaching errors" on which the author treated his readers. ${ }^{82}$ Especially Dozy's etymological inferences elicited fierce criticism. As Meijer Roest declared in the Nieuw Israëlietisch Weekblad: "These hypotheses rest on textual conjectures that teach us an Hebrew which would make an Isaiah's hair stand on end..." ${ }^{83}$ To be sure, the point was not that Dozy made factual errors, although some Jewish critics were eager to point out that Dozy's command of the Hebrew language did not surpass that of a "Jewish school boy." 84 The point was rather that the way for such errors was paved by what Ludwig Philippson called the "levity" of Dozy's working manners. ${ }^{85}$

In this context, Dozy was also found guilty of other vices. Critics seeking to express a greater sense of indignation spoke about intellectual "audacity." According to the DutchJewish critic Philip Elte, for example, it was an "insolence" (aanmatiging) and "impudence" (brutaliteit) to present far-reaching hypotheses without a proper awareness of complications and alternatives. ${ }^{86}$ Others qualified Dozy's findings as "premature" (voorbarig), given that they ran ahead of more thorough and detailed study. ${ }^{87}$ This accusation stemmed from the

\footnotetext{
${ }^{82}$ Ewald, review, 1270.

${ }^{83}$ X+Y [pseudonym of Meijer Roest Mzn.], "Boekbeschouwing," Nieuw Israëlietisch Weekblad (18 August 1865).

${ }^{84}$ Elte, Moderne theologie, 30.

${ }^{85}$ [Ludwig Philippson], "Literarischer Wochenbericht," Allgemeine Zeitung des Judenthums, 32 (1868), 834.

${ }^{86}$ Elte, Moderne theologie, 30.

${ }^{87}$ Kuenen, "Baälsdienst onder Israël," 481.
} 
belief (briefly referred to above) that all relevant "facts" had to be established before a scholar could hazard an "interpretation." As the Leiden historian Robert Fruin recommended in 1865: "Do not begin with the building before the material has been gathered and prepared." 88

Finally, Dozy was accused of "prejudice" and "dogmatism," because of his tendency to explain difficult passages so as to make them fit his purposes. Whoever translates gilgal with "round heap of stones," wrote the Reformed pastor C. H. van Herwerden, does not do so on etymological grounds, but out of "love for his theory." ${ }^{, 89}$ Likewise, J. P. N. Land declared: "Captivated by the idea that Jahwist scribes had reworked the older history in their own manner, [Dozy] is often satisfied with particularly weak arguments as long as these contribute to portraying ancient Israel as thoroughly pagan." 90 Accordingly, Henricus Oort, the future Leiden professor of theology, concluded that Dozy had succumbed to a classic temptation:

If one thinks one has found a track that yields surprising results, one is easily temped to follow that track, to put in the forefront whatever seems to prove its correctness, and to close the eye to everything that speaks against it. One quickly finds what one hopes to find; this leads many an acute man of learning astray. ${ }^{91}$

\footnotetext{
${ }^{88}$ R. Fruin, "De drie tijdvakken der Nederlandsche geschiedenis,” De Gids, 29 (1865), II, 245-71, at 245 .

${ }^{89}$ Van Herwerden, "Steenen- en boomendienst," 395.

${ }^{90}$ Land, "Nieuwe lichtstraal," 229.

${ }^{91}$ Oort, Dienst der Baälim, 5, approvingly quoted in Van Herwerden, “Steenen- en boomendienst," 397-8.
} 
As a matter of fact, not only Dozy, but also his crowd of enthusiastic followers was accused of such dogmatism. As the Nieuw Israëlietisch Weekblad declared in a biting comment on the debate:

Professor Dozy writes "The Israelites in Mecca” and all liberal theologians, headed by Prof. De Goeje, look on amazed and struck dumb by those heavenly revelations from Sinai, no at Leiden. They are inexhaustible in their cheers, they dance and shout with joy like the Egyptians when Apis honors them with a visit. Kuenen writes "The Religion of the Israelites" [in the same series, "The Most Important Religions," in which Dozy's Het islamisme had appeared] and the entire choir of liberal theologians sings Hallelujah, yea is seized with convulsion caused by joy. So it is hardly possible for our pastors not to vow on the oracles of the great masters who, for the benefit of their loyal, credulous disciples, are busily brewing brand new revelations. ${ }^{92}$

Dozy for his part complained about the vices of his critics. In correspondence with his publisher, he accused the Jewish scholar Moritz Steinschneider of "dishonesty" (oneerlijkheid) in summarizing his arguments ${ }^{93}$ and Meijer Roest of systematically

92 "Beoordeling der review van het Handboek voor de geschiedenis der Joden door Sluijs en Hoofiën in het Leeskabinet,” Nieuw Israëlietisch Weekblad (28 July 1871). See also Elte, Moderne theologie, 9.

${ }^{93}$ LUL, LTK 1505, Dozy to Kruseman, 13 November 1864. On Steinschneider's warm connection with Leiden, see Jan Just Witkam, "Moritz Steinschneider and the Leiden Manuscripts," in Reimund Leicht and Gad Freudenthal, eds., Studies on Steinschneider: Moritz Steinschneider and the Emergence of the Science of Judaism in Nineteenth-Century Germany (Leiden, 2012), 263-75. 
"distorting" his position and wrenching words from their context - abuses that he attributed to "helpless anger" (magtelooze woede) and "theological hatred." 94 In Dozy's view, Ewald also collected vices by the dozen by taking "the celebrity of any opinion not emanating from himself" as a "sufficient reason for condemning and contradicting it." ${ }^{95}$ So, at first sight, it seems as if Dozy and his critics all proceeded from the assumption that scholarship would flourish as long as virtues would be practiced and vices avoided.

\section{Constellations of virtues}

Crucial, however, was that unanimity about the relative importance of these virtues and vices did not exist. We already noticed that "frankness" was considered a virtue only as long as it was practiced to a right extent. This explains why Graf could condemn excessive "stoutheartedness" as "adventurousness"96 and why Kuenen did not complain about Dozy's method as such, but rather about its exaggeration: "So between Dozy and myself, only a difference as between more and less exists." ${ }^{97}$ What mattered, therefore, was a right dose of frankness. But what counted as such a proper dose? Whereas some believed that the Leiden Orientalist was

\footnotetext{
${ }^{94}$ LUL, LTK 1505, Dozy to Kruseman, 19 September 1864.

${ }^{95}$ Ibid., Dozy to Kruseman, 6 September 1864, quoting R. W. MacKay, The Tübingen School and Its Antecedents: A Review of the History and Present Condition of Modern Theology

(Edinburgh, 1863), 345. Dozy seems to have borrowed these quotations from David Friedrich Strauss, given that Mackay's remarks about Ewald quoted in Dozy's letter to Kruseman are identical to those quoted in Strauss, Das Leben Jesu für das deutsche Volk bearbeitet (Leipzig, 1864), 158 n. 2.

${ }^{96}$ Graf, review, 332, 338.

${ }^{97}$ Kuenen, "Simeonieten en Ismaëlieten," 513.
} 
guilty of "pretentious" and "insolent" conduct, others appreciated his "bold" and "daring" ideas.

This divergence, in turn, was related to the degree in which the critics saw Dozy's virtues as being kept in balance by other virtues. If shrewdness is not checked by accuracy, wrote Graf, an etymologist can "make anything out of everything." And if the "sense of detection" that comes with well-developed shrewdness is not to deteriorate into phantasy, it has to be restrained by methodical "rules and laws." 98 In a similar vein, Philippson sighed:

For a long time, experience has taught that learning and shrewdness are not sufficient for practicing true criticism, but that it also takes a dose of common sense. One knows what kind of absurdities have been put forward these days by very learned and shrewd critics, because they were just learned and shrewd, but did not possess sufficient common sense to set a limit to their critical nonsense. ${ }^{99}$

In this view, then, historical research required constellations of virtues, that is, well-balanced combinations of, say, shrewdness and reliability, or frankness and skepticism vis-à-vis adventurousness. Scholars were, in other words, not supposed to practice single virtues at the expense of others. This has an important implication for the study of virtue language in

${ }^{98}$ Graf, review, 345. Similarly: A. Kuenen, Historisch-kritisch onderzoek naar het ontstaan
en de verzameling van de boeken des Ouden Verbonds, vol. 3 (Leiden, 1865), 220 and H. E. Stenfert Kroese, review of Pierson, De heilige steenen in Israël, Vaderlandsche Letteroefeningen, 105 (1865), 476-88, at 477.

${ }^{99}$ [Philippson], review, 589. Cf. Bernheim, Lehrbuch der historischen Methode, 297: “One sees, successful maintenance of this method requires not only shrewdness, but also careful cautiousness." 
nineteenth-century scholarship. If relations between virtues were as important as the passages just quoted suggest, then a key element of this virtue discourse is ignored as long as historical epistemologists focus just on individual virtues.

There are two further reasons as to why questions like "Did Dozy possess a talent for conjecture?" and "What did accuracy mean in the 1860s?" are misleading in their simplicity. One is that several participants in the debate believed in scholarly divisions of labor and, consequently, in differentiated requirements for individual scholars. Pierson, for example, declared with an allusion to Paul's first letter to the Corinthians $(12,4)$ that there are "diversities of spirits": "it is another that criticizes and another that makes conjectures. The special intellectual gifts of the shrewd critic [den scherpzinnigen beoordelaar] are not easy to reconcile with the ability to conjure [het vermogen om te combineren] that is the first requirement for forming hypotheses. ${ }^{, 100}$ Following this line of reasoning, Dozy could allow himself one-sidedness in order to correct the one-sidedness of others. In a debate that tended to get bogged down in details, an overdose of frankness was, in Pierson's view, less inappropriate than in a debate that badly needed cautious testing of wild hypotheses.

Varying on this argument, other reviewers mentioned the stimulus provided by Dozy's intervention. The German-Jewish Orientalist Gustav Weil, for example, expected that, despite or precisely because of its forced inferences and unlikely hypotheses, De Israëlieten te Mekka would give a major impetus to new research, "which will further scholarship."101 Matthes, too, stated that "this work stimulates one's thought and inspires new, serious research."102 Pierson even wondered what was wrong with periodical eruptions of shrewdness and creativity like Dozy's. “As long as we do not value our phantasies as positive proofs and

\footnotetext{
${ }^{100}$ Pierson, Heilige steenen, 9.

${ }^{101}$ [Weil], review, 602.

${ }^{102}$ Matthes, “Nieuwe ontdekking," 369.
} 
regard them tentatively as nothing more than experiments, I do not think there is any objection against making them public." ${ }^{\prime 103}$ Although this might have been said out of politeness, the words just quoted express a view of scholarship in which not an individual's result, but the contribution that individuals make to an ongoing scholarly conversation counted as most important. In so far as Weil, Matthes, and Pierson endorsed this view, they assigned less weight to an individual's ability to achieve a balance of virtues than to a balance achieved over time, by the collective efforts of the scholarly community. ${ }^{104}$

In sum, then, the debate prompted by Dozy's book reveals no less than four reasons as to why virtues in nineteenth-century scholarly discourse cannot be studied in isolation from each other. The extent to which Oriental and Biblical scholars in the 1860s welcomed accuracy, shrewdness, and frankness depended on (1) the extent to which these virtues were practiced, (2) the extent to which they were kept in balance by other virtues, (3) the extent to which they were balanced by other scholars' virtues, and (4) the extent to which it was expected that they would be balanced by future scholars' work.

\section{A divided house}

The fact that all these variables figured in the debate prompted by De Israëlieten te Mekka does not, of course, imply that all participants assigned equal importance to them. We have observed that Dozy's critics did not agree on the criteria for measuring (1), that they differed on the relative importance of (2), and that, for authors such as Ewald and Philippson, (3) and (4) hardly played a role at all. In other words, Dozy's critics employed different standards of inquiry and, consequently, arrived at different judgments about the scholarly value of Dozy's

\footnotetext{
${ }^{103}$ Pierson, Heilige steenen, 9.

${ }^{104}$ For a similar attitude among late nineteenth-century British scientists, see Matthew

Stanley, Practical Mystic: Religion, Science, and A. S. Eddington (Chicago, 2007), 46-9.
} 
book. While Land evaluated it as a scholarly contribution par excellence, ${ }^{105}$ Ewald and Philippson concluded that De Israëlieten te Mekka had nothing whatsoever to do with "true scholarship." 106 The French Orientalist Gustave Dugat therefore hit the nail on the head: "This book is, according to some, the best and, according to others, the worst of all [Dozy] has written."107

As Ran HaCohen has shown, confessional divisions contribute much to explaining this divergence of views. ${ }^{108}$ By and large, orthodox Jews were more skeptical of modern Biblical criticism than their liberal fellow-believers, just as Calvinist voices in the controversy over $D e$ Israëlieten te Mekka were, with some exceptions, more dismissive of Dozy's methodology than liberal ones. However, not all difference with regard to the variables (1) to (4) can so easily be explained under reference to religious positions on a spectrum between orthodoxy and liberalism. Constellations of virtues also depended on methodological beliefs, two of which need to be signaled out here in order to explain the mixed response that Dozy drew even among scholars with broadly similar theological views.

One matter in dispute was the question whether Biblical or Oriental scholarship still lived up to its wissenschaftliche vocation if it left the realm of philological detail in order to engage in work of synthesis. As Sabine Mangold and others have shown, among German Orientalists in the mid-nineteenth-century the prestige of philological precision as advocated by Heinrich Leberecht Fleischer and his numerous pupils was such that their philological

${ }^{105}$ Land, "Nieuwe lichtstraal," 229.

${ }^{106}$ [Philippson], review, 589, 590; Ewald, review, 1271-2.

${ }^{107}$ Gustave Dugat, Histoire des orientalistes de l'Europe du XIIe au XIXe siècle, vol. 2 (Paris, 1870), 61.

${ }^{108}$ See note 7 above. 
ethos came close to being identified with Wissenschaft as such. ${ }^{109}$ This left little room for the more ambitious view expounded by Kuenen, among others, that narrative synthesis was the end of all scholarship - even though it might take a lifetime, or even generations, to prepare a proper, critical "foundation" for it. ${ }^{110}$ The more, indeed, Dozy's critics identified philological precision with scholarship as such, the shaper was their verdict about "the witty, cheerful Dozy," as the Swedish Orientalist Carlo Landberg put it condescendingly in $1886 .{ }^{111}$ In the years following the publication of De Israëlieten te Mekka, a second methodological fault line emerged among Orientalists in Europe. While Dozy belonged to a generation that considered classical texts as their most important objects of study, during the 1880s this approach increasingly met with opposition from ethnographically oriented modes of study that paired texts to other kinds of source material and used these texts, not as worthwhile in themselves, but as means for addressing non-philological questions. Dismissive of the philologische Kleinarbeit embodied by Fleischer and, especially, his students, a younger generation of Orientalists, which included such future heavyweights as Ignác Goldziher and Martin Hartmann, deliberately focused on historical and anthropological questions, which required more than the philological methods that had dominated Orientalism

${ }^{109}$ Mangold, Weltbürgerliche Wissenschaft, 91-5; Marchand, German Orientalism, 74-84; Hans-Georg Ebert and Thoralf Hanstein, eds., Heinrich Leberecht Fleischer, Leben und Wirkung: ein Leipziger Orientalist des 19. Jahrhunderts mit internationaler Ausstrahlung (Frankfurt am Main, 2013).

${ }^{110}$ A. Kuenen, "Critical Method - I," The Modern Review, 1 (1880), 461-88, at 466.

${ }^{111}$ Comte de Landberg, Critica arabica, vol. 1 (Leiden, 1886), 18. 
in the mid-nineteenth century. ${ }^{112}$ Unsurprisingly, such protests against the philological ethos of the Fleischer school emerged not only in Europe. Ottoman scholars, too, complained about European professors who pretended to be specialists in Arabic without ever having taken the trouble of leaving their study or library. From Beirut, for example, Ibrahim al-Yaziji judged about Dozy:

In spite of all research proficiency, in spite of the high ambitions, in spite of all patience in observing and writing, the man lacked the best means for understanding the Arabic language, the classical and the modern alike, because, to our knowledge, he has never traveled to one of the Arabic-speaking countries, such as Egypt or Syria, and conversed orally with only few Arabs, but learned the language solely from books, with help of people among his fellow-countrymen whom are called Orientalists. ${ }^{113}$

Near the time of Dozy's death, similar criticisms came to be heard at Leiden. In 1880, De Goeje's most talented pupil, Christiaan Snouck Hurgronje, did not devote his doctoral dissertation to old Arabic texts, but to the still-existing "Meccan festival." Moreover, among the sources Snouck consulted for this study were such unconventional ones as travelogues of recent Western visitors to Mecca. ${ }^{114}$ A few years later, in 1884, Snouck would even undertake an expedition to Mecca in order to see the center of Islam with his own eyes. With such

\footnotetext{
${ }^{112}$ Mangold, Weltbürgerliche Wissenschaft, 254; Ursula Wokoeck, German Orientalism: The Study of the Middle East from 1800 to 1945 (London, 2009), 170-84; Ottfried Fraisse, Ignác Goldzihers monotheistische Wissenschaft: zur Historisierung des Islams (Göttingen, 2014). ${ }^{113}$ Cited after H. L. Fleischer, "Eine Stimme aus dem Morgenlande über Dozy’s Supplément aux dictionnaires arabes," in Fleischer, Kleinere Schriften, vol. 3, 615-41, at 619-20. ${ }^{114}$ Christiaan Snouck Hurgonje, Het Mekkaansche feest (Leiden, 1880), 9-10.
} 
“fieldwork," usually on behalf and/or with financial means provided by the Dutch colonial administration, Snouck embarked on a new type of research. Some polite words about his Doktorgroßvater notwithstanding, Snouck's scholarship of the 1880 s displayed very little affinity with Dozy's work in the 1860s. Not only Dozy's “speculation,” but also his philological "groundwork" was called into question. ${ }^{115}$

If methodological fault lines, apart from confessional dividing lines, help explain the different views that Dozy's critics adopted vis-à-vis the variables (1) to (4) identified in the previous section, can the same be said about their academic affiliations, or the lack thereof? Nineteenth-century Orientalism was, after all, a field in which academics found themselves accompanied by what Lawrence Conrad calls "a broad range of explorers, adventurers, and

${ }^{115}$ As P. S. van Koningsveld has shown in "Snouck Hurgronje zoals hij was: een bijdrage tot de waardering van de Nederlandse oriëntalistiek," De Gids, 143 (1980), 763-84, at 765-70, Snouck's criticism of Dozy became more and more negative over the years. In Leiden, this dissociation from Dozy was sharply felt, witness the fact that in 1883, right after Dozy's death, De Goeje made a lengthy attempt at explaining Dozy's "faux pas" of 1864. The following year, Dozy's biographer, the Dutch-Jewish scholar Levi de Hartog, judged it wise to pass over De Israëlieten te Mekka in silence. Nonetheless, as late as 1894, the Leiden church historian J. G. R. Acquoy - the man we met in the opening paragraph as pastor in Zaltbommel at the time of Marx's visit - referred to Dozy's book as a "splendid example of historical combination." See De Goeje, "Levensbericht van Reinhart Dozy," 37-9; L. de Hartog, Reinhart Pieter Anne Dozy (Haarlem, 1884); J. G. R. Acquoy, Handleiding tot de kerkgeschiedvorsching en kerkgeschiedschrijving (The Hague, 1894), 86-7, as well as Snouck’s final (devastating) verdict in C. Snouck Hurgronje, “Michaël Jan de Goeje,” in Jaarboek van de Koninklijke Akademie van Wetenschappen gevestigd te Amsterdam 1909 (Amsterdam, 1910), 107-46, at 117. 
travelers: missionaries, theologians, and preachers; eccentrics, frauds, and crackpots; social reformers, political advocates, soldiers, spies, and diplomatic representatives of various European regimes."116 Although not all of these intervened in the debate over De Israëlieten te Mekka, the company of Dozy's critics indeed included quite a few non-academic scholars, such as rabbis, pastors, and journalists. It would be mistaken, however, to assume that those with university positions distinguished themselves en bloc from those without. One reason is that pastors could be future professors, or eager to present themselves as such, as illustrated by Henricus Oort (who obtained a chair after twelve years of pastoral service). ${ }^{117}$ Another is that academic affiliation as such did not make a serious conversation partner: the Göttingen professor Heinrich Ewald was depicted in the blackest possible terms by several of his colleagues ("a self-deifying man [Selbstvergötterer] who is more or less ripe for the madhouse," Fleischer judged in 1865). ${ }^{118}$

Robert Irwin therefore rightly concludes that "there was hardly an Orientalist type or a common Orientalist discourse" in Europe, especially once the heydays of the Fleischer school

${ }^{116}$ Lawrence I. Conrad, “The Dervish’s Disciple: On the Personality and Intellectual Milieu of the Young Ignaz Goldziher," Journal of the Royal Asiatic Society of Great Britain and Ireland, 2 (1990), 225-66, at 265.

${ }^{117}$ C. E. Hooijkaas, "Levensbericht van Henricus Oort, 27 december 1836-13 december 1927," Handelingen en mededeelingen van de Maatschappij der Nederlandsche Letterkunde te Leiden, over het jaar 1928-1929 (Leiden, 1929), 77-126, at 85.

${ }^{118}$ LUL, BPL 2389, Fleischer to De Goeje, 17 March 1865. For similar criticism, see ibid., Dozy to De Goeje, 11 October 1864; ibid., LTK 1505, Dozy to Kruseman, 6 September 1864. On Ewald's dubious reputation, see also Lothar Perlitt, "Heinrich Ewald: der Gelehrte in der Politik," in Bernd Moeller, ed., Theologie in Göttingen: eine Vorlesungsreihe (Göttingen, 1987), 157-212, at 181-94. 
were over. ${ }^{119}$ In religious, methodological, as well as institutional respects, diversity seemed the norm. Perhaps this makes it all the more significant that none of Dozy's critics judged De Israëlieten te Mekka by the standard of a single virtue, but weighed the author's virtues and vices, even while putting forward different catalogues of virtues. So, if even Orientalists of the most varied stripes agreed that constellations of virtues mattered more than accuracy or shrewdness as such, shouldn't this insight be taken to heart by historical epistemologists working on virtues and vices in nineteenth-century scholarly discourse?

\section{Conclusion}

My primary purpose in examining the reception history of De Israëlieten te Mekka has not been to develop new insight into mid-nineteenth-century Orientalism. Instead, I have examined the controversy surrounding Dozy's book in order to raise a methodological issue regarding the study of what Lorraine Daston calls "the history of categories that structure our thought." ${ }^{120}$ Although it is widely recognized that these categories include virtues and vices, historical epistemologists and intellectual historians more generally have studied these virtues and vices almost exclusively on an individual base, without sufficiently recognizing that the meaning and significance of such virtues and vices in actual scholarly practice depended to no small degree on their relations to other, competing, complementary, and/or overlapping virtues and vices. More specifically, the 1864 controversy analyzed in this article suggests that what qualified as virtues in the context of mid-nineteenth-century Biblical and Oriental studies depended on (1) the extent to which shrewdness, frankness, and so forth were practiced, (2) the extent to which these virtues were kept in balance by other virtues, (3) the extent to which they were balanced by other scholars' virtues, and (4) the extent to which it

\footnotetext{
${ }^{119}$ Irwin, For Lust of Knowing, 197.

${ }^{120}$ See note 12 above.
} 
was expected that they would be balanced by the work of future scholars. Even though some Orientalists, such as Ewald, rejected the variables (3) and (4), the fact that they deemed it irrelevant to judge Dozy's work in the light of other scholars' contributions reveals that they had taken a stance on these issues with implications for what they recognized as proper, “virtuous" scholarly conduct.

Secondly, the controversy examined in this article reveals that Orientalists and Biblical scholars in the 1860s subscribed to different catalogues of virtues and, consequently, failed to reach agreement on standards of "virtuous" scholarly conduct. I have argued that this disagreement did not merely exist between "professionals" and "amateurs," or between scholars in and outside the academy, but within the worlds of Biblical and Oriental studies themselves. This divergence increased, moreover, when in the 1880 s a younger generation of Orientalists began to rebel against the philological inheritance of the Fleischer school. This implies that constellations of virtues, as I have called them, were fragile in at least two respects. Not only were scholars supposed to keep a delicate balance between a number of different virtues, but also the equilibrium itself was unstable, given that the assumptions defining what constituted a constellation of virtues were subject to change.

In order to give such constellations of virtues the attention they deserve, historical epistemology as currently practiced needs more than just expansion of its focus on individual virtues. It also needs to supplement the study of ideals of virtue such as articulated in programmatic texts (inaugural addresses) and codifying manuals (educational textbooks) with detailed examination of how virtues and vices actually functioned in the context of scholarly debates, controversies, and polemics. For the relative significance of "impartiality" or "shrewdness" was nowhere as apparent as when catalogues of virtues and vices clashed. What noble ideals of virtue were worth in day-to-day scholarly practice became nowhere as clear as 
when they were challenged by competing ideals. ${ }^{121}$ So, if historical epistemologists or intellectual historians more generally want to understand how and to what extent virtues and vices "structured" scholarly research and "patterned" scholarly discourse, these virtues and vices are best studied in such concrete historical settings as a journal's book review section or a scholarly debate on the origins of Islam.

${ }^{121}$ On scholarly controversies as historical sources, see Klaus Große Kracht, "Kritik, Kontroverse, Debatte: Historiografiegeschichte als Streitgeschichte," in Jan Eckel and Thomas Etzemüller, eds., Neue Zugänge zur Geschichte der Geschichtswissenschaft (Göttingen, 2007), 255-83. 